\title{
Effect of Different Levels of Dietary Selenium on growth performance and nutrient utilization of broiler birds
}

\author{
Ankur Khare* and R.P.S Baghel \\ College of Veterinary Science and A.H., \\ M.P.P.C.V.V., J abalpur (M.P.), India. \\ * Corresponding author email : ankur_khare29@yahoo.com
}

\begin{abstract}
Experiment was conducted on 120 broiler chicks for six weeks and their weight gain was taken for consecutive six weeks to observe the effect of different levels of dietary selenium over growth and nutrient utilization of birds. There were three diets prepared with $0.125,0.15$ and $0.175 \mathrm{mg} \mathrm{Se} / \mathrm{Kg}$ feed for group T1, T2 and T3 respectively. The FCR and performance index at $1^{\text {st }}$ week for T1 were $1.34 \pm 0.02$ and $21.21 \pm 0.36$ that for T 2 was $1.51 \pm 0.01$ and $16.56 \pm 0.40$ and for T3 were $1.29 \pm 0.02$ and $23.88 \pm 0.50$, the experiment continues for 6 weeks the FCR and performance index at $6^{\text {th }}$ week in $\mathrm{T} 1, \mathrm{~T} 2$ and T3 was $3.42 \pm 0.19$ and $7.37 \pm 0.78,3.56 \pm 0.05$ and $6.51 \pm 0.25,3.56 \pm 0.15$ and $6.85 \pm 0.58$. The percent retention of nutrients was highest in T3 group as compare to T1 and T2 which was supplemented @ $17.50 \mathrm{mg}$ Se/kg of feed. Therefore it was concluded that supplementation of selenium @ $17.50 \mathrm{mg} / \mathrm{kg}$ diet of poultry enhances the growth rate as well as nutrient retention in the broiler birds.
\end{abstract}

Keywords: FCR, Performance index, Selenium, Nutrient utilization, Nutrient, weight gain.

\section{I ntroduction}

Selenium is an essential trace element occurring in organic and inorganic forms. The organic form is found predominantly in grains, fish, meat, poultry, and dairy products (Klein, 2004). Selenium has been shown to have an analogous function as an essential component of the Se-dependent glutathione peroxidase (Combs, 1981). This enzyme protects cells against damage caused by free radicals (Flohe, 1997). The supplementation of feeds with $\mathrm{Se}$ is achieved with mainly inorganic sources of $\mathrm{Se}$ such as $\mathrm{Na}_{2} \mathrm{SeO}_{3}$ (sodium selenite). High levels of dietary Se result in higher liver, kidney, plasma, and muscle Se concentrations in poultry (Echevarria et al., 1988).

Selenium is an essential micronutrient required for normal growth and maintenance in poultry. The recommended selenium concentration in broiler diet is $0.15 \mathrm{mg} / \mathrm{kg}$ (NRC, 1994). Swain et al. (2000) reported the maximum daily weight gain and highest feed conversion in chickens that received $0.50 \mathrm{mg}$ $\mathrm{Se} / \mathrm{kg}$ and $300 \mathrm{IU} / \mathrm{kg}$ vitamin $\mathrm{E}$.

The present study was conducted to determine the effect of various dietary levels of supplemental Se on the growth performance and nutrient utilization of broiler chickens.

\section{Materials and Methods}

Birds and Diets: The experiment was conducted on one hundred twenty broiler chicks (1 d old) were randomly assigned to 12 cages containing 10 chicks each, corresponding to each of 3 dietary treatments. The ingredients and composition of the starter and basal diets are shown in Tables 1. Treatment 1 (T1) contains $25 \mathrm{mg}$ (200 kg feed) (@ $0.125 \mathrm{mg} / \mathrm{kg}$ of diet) selenium while, T2 diet contains $30 \mathrm{mg}$ (@0.15 mg/kg of diet) selenium and diet T3 contains 35 mg (@0.175 $\mathrm{mg} / \mathrm{kg}$ of diet) selenium. The chicks were maintained on a 24-h constant lighting schedule and allowed access to feed and water $a d$. lib. until slaughter at 42 day of age. The body weight and feed consumption for the individual pens were recorded at 1, 7, 14, 21, 32, and $42 \mathrm{~d}$. Before slaughter of birds three days metabolic trial was conducted to observed the effect of dietary selenium over the nutrient utilization of the birds. Percent composition of concentrate mixture given to the chicks was presented in table 01 .

Metabolic trial: At the end of the feeding trial, four (4) birds per replicate were randomly selected and transferred to metabolic cages for faecal collection to determine the apparent nutrient digestibility. The birds were allowed to adjust to the cages for three days. The digestibility trial lasted 4 days. The total collection procedure was employed for the faecal collection. Polythene sheet spread underneath the cages was used for faecal collection. Feathers and other dirts were hand picked and discarded from the faeces before weighing. 
Effect of Different Levels of Dietary Selenium on growth performance and nutrient utilization of broiler birds

Table-1. Percent composition of concentrate mixture along with the composition of selenium in individual diets.

\begin{tabular}{clccccc}
\hline Sr. No. & Ingredients & Composition $\mathbf{( K g )}$ & \% Composition & T1 & T2 & T3 \\
\hline 1. & Maize & 120.00 & 60.00 & - & - & - \\
2. & DORP & 18.00 & 9.00 & - & - & - \\
3. & SBM & 54.84 & 27.42 & - & - & - \\
4. & Mineral Mixture & 6.00 & 3.00 & - & - & - \\
5. & Lysine & 0.30 & 0.15 & - & - & - \\
6. & Methionine & 0.40 & 0.20 & - & - & - \\
7. & Vitamin AD3 & 0.03 & 0.015 & - & - & - \\
8. & Vitamin B-complex & 0.03 & 0.015 & - & - & - \\
9. & Novatox & 0.2 & 0.1 & - & - & 35 \\
10. & Improval & 0.2 & 0.1 & -- & 30 & \\
11. & Selenium (mg) & - & 100 & & & \\
& Total & $200 \mathrm{Kg}$ & & & & \\
\hline
\end{tabular}

Table-2. Overall performance of the broiler ( 0-6 week)

\begin{tabular}{cccccc}
\hline Sr. No. & Treatment & Wt. gain/day/bird(gm) & Feed intake/day/bird(gm) & FCR & PI \\
\hline 1 & 1R & $27.27 \pm 2.46$ & $66.84 \pm 9.01$ & $2.61 \pm 0.47$ & $12.80 \pm 2.94$ \\
2 & 2R & $25.36 \pm 2.77$ & $66.50 \pm 8.92$ & $2.73 \pm 0.44$ & $10.81 \pm 2.11$ \\
3 & 3R & $28.02 \pm 3.57$ & $68.02 \pm 8.94$ & $2.61 \pm 0.47$ & $13.40 \pm 3.31$ \\
\hline
\end{tabular}

The collections for each day were dried in a hot air oven at $60^{\circ} \mathrm{C}$. The samples of each replicate were allowed to cool in glass desiccators to prevent further absorption of moisture from the atmosphere. The 4 days samples were pooled, ground and then analyzed for crude protein, crude fibre, ether extract and total ash according to the method of AOAC (2003).

\section{Results and Discussion}

Performance of the broiler was determined by observing their body weight at weekly intervals. The overall average body weight of the birds from 0-6 weeks were presented in the Table- 2 .

Performance of Broiler Chicks: The different level of selenium in the diet of the broiler bird from 0 week to 6 week of age doesn't have any significant effect on the weight gain. The average weight gain of the birds from the age of 0-6 weeks ranges from 25.36 to 28.02 g. Average feed intake per day per bird during 6 week period ranges from $66.50 \mathrm{~g}$ in group II to $68.02 \mathrm{~g}$ in group III. Feed conversion ratio (FCR) was similar in group I and group III i.e. 2.61 and slightly higher in group II i.e. 2.73. Performance Index in all the three groups for the period of 6 weeks ranges from 10.81 in group II to 13.40 in group III. The results were in agreement with the results of Guo et al. (2001) and Ryu et al. (2005). Average data of the performance for the period of 0-6 weeks is presented in Table 02 below. Nutrient Utilization of the Bird: Metabolic trial is conducted for 7 days to evaluate the nutrient

utilization of the birds in all the three supplemented groups. The concentrate mixture was analysed for dry matter, crude protein, crude fibre and ether extract by the method of A.O.A.C (1980). The chemical composition of concentrate mixture fed to the birds at the time of metabolic trial was presented in Table-3.

The faecal sample collected during the metabolic trial was chemically analyzed for dry matter, crude protein, crude fibre and ether extract as per the method by A.O.A.C (1980). The chemical composition of faecal samples was presented in the Table -3.

The percent retention of nutrients was calculated by calculating the total intake and total outgo of the nutrients. Such as in group I the DM intake during the period of metabolic trial was $167.83 \mathrm{~g}$ while outgo was $43.12 \mathrm{~g}$ therefore the percent retention of DM was 74.30. Same as that of protein the percent retention was $68.71 \%$, Crude fiber retention in group I was $77.41 \%$ and that of ether extract was $84.84 \%$. Nutrient retention in group I was lowest among all the three supplemented groups. Percent retention of nutrients in group I was presented in Table-4.

In group II the percent retention of DM was found to be 85.43 while, protein comes to be $71.44 \%$ that of crude fiber and ether extract was $77.71 \%$ and $85.56 \%$ respectively. Group II was the control group the retention of nutrients was higher then the group I but lower than the group III.

Retention of nutrients was found to be highest in 
Effect of Different Levels of Dietary Selenium on growth performance and nutrient utilization of broiler birds

Table-3. Chemical composition of concentrate mixture and faecal samples

\begin{tabular}{|c|c|c|c|c|c|}
\hline \multicolumn{6}{|c|}{ Chemical Composition of Concentrate Mixture } \\
\hline S. No. & DM (\%) & CP (\%) & CF (\%) & EE (\%) & \\
\hline 1. & 94.08 & 11.62 & 4.25 & 25.6 & \\
\hline \multicolumn{6}{|c|}{ Chemical Composition of Faecal Samples } \\
\hline S. No. & Treat & DM (\%) & CP (\%) & CF (\%) & EE (\%) \\
\hline $\begin{array}{l}1 . \\
2 . \\
3 .\end{array}$ & $\begin{array}{l}1 \mathrm{R} \\
2 \mathrm{R} \\
3 \mathrm{R}\end{array}$ & $\begin{array}{l}27.63 \\
24.48 \\
16.84\end{array}$ & $\begin{array}{l}23.31 \\
22.78 \\
21.20\end{array}$ & $\begin{array}{l}6.17 \\
6.50 \\
7.79\end{array}$ & $\begin{array}{l}24.88 \\
25.39 \\
26.54\end{array}$ \\
\hline
\end{tabular}

Table-4. Retension of nutrients in Group I, Group II and Group I I I.

\begin{tabular}{ccccc}
\hline Group & Nutrients & Intake (gm/day/bird) & Outgo (gm/day/bird) & \% Retention \\
\hline 1. & DM & 167.83 & 43.12 & 74.30 \\
& CP & 19.50 & 6.10 & 68.71 \\
& CF & 7.13 & 1.61 & 77.41 \\
2. & EE & 42.96 & 6.51 & 84.84 \\
& DM & 158.55 & 23.10 & 85.43 \\
& CP & 18.42 & 5.26 & 71.44 \\
3. & CF & 6.73 & 1.50 & 77.71 \\
& EE & 40.59 & 5.86 & 85.56 \\
& DM & 159.18 & 17.31 & 89.12 \\
& CP & 18.49 & 3.67 & 80.15 \\
& CF & 6.76 & 1.34 & 80.17 \\
\hline
\end{tabular}

group III among all the three experimental groups. The DM retention was $89.12 \%$ that of crude protein, crude fiber and ether extract was $80.15 \%, 80.17 \%$ and $88.73 \%$ respectively. Percent retention of nutrients in group III was given in Table-4.

\section{Acknowledgement}

Authors want to acknowledge the Hon'ble Vice Chancellor Dr. G.P.Mishra and Dean Faculty for their invaluable support and continuous motivation during research.

\section{References}

1. AOAC. (2003). Official Methods of Analysis. 17th ed. Association of Official Analytical Chemists, Arlington, VA.

2. Combs, G. F., Jr. (1981). Influences of dietary vitamin E and selenium on the oxidant defense system of the chick. Poult. Sci., 60:2098-2105.

3. Echevarria, M. G.; Henry, P. R.; Ammerman, C. B.; Rao, P. V. and Miles, R. D. (1988). Estimation of the relative bioavailability of inorganic selenium sources for poultry. 1 .
Effect of time and high dietary selenium on tissue selenium uptake. Poult. Sci., 67:1295-1301.

4. Flohe, L. (1997). Selenium in peroxide metabolism. Med Klin. 92:5-7.

5. Guo, Y.; Tang, Q., Yuan, J.; and Jiang, Z. (2001). Effects of supplementation with vitamin $\mathrm{E}$ on the performance and the tissue peroxidation of broiler chicks and the stability of thigh meat against oxidative deterioration. Anim. Feed Sci. Technol. 89:165-173.

6. Klein, E. A. (2004). Selenium: Epidemiology and basic science. J. Urol. 171:S50-S53.

7. National Research Council (1994). Nutrient Requirements of Poultry. $9^{\text {th }}$ edn. Washington, DC, National Academy Press. 27-31.

8 Swain, B.K.; Johri, T.S. and Majumdar, S. (2000). Effect of supplementation of vitamin E, selenium and their different combinations on the performance and immune response of broilers. Brit. Poult. Sci., 41: 287-292.

9. S.P. Bobade, A.N. Sarag, D.H. Rekhate, A.P. Dhok and S.V. Joge (2009). Efficacy of Vitamin E and Selenium on Growth Performance of Broilers. Vet. World, 2(1):20-21

9. Ryu, Y.C.; Rhee, M.S.; Lee, K.M. and Kim, B.C. (2005). Effects of different levels of dietary supplemental selenium on performance, Lipid Oxidation, and Color Stability of Broiler Chicks. Poult. Sci., 84: 809-815. 